\title{
GROWTH AND PRODUCTIVITY OF SUGARCANE VARIETIES UNDER VARIOUS IRRIGATION LEVELS ${ }^{1}$
}

\author{
CICERO TEIXEIRA SILVA COSTA ${ }^{2 *}$, JOÃO CARLOS CURY SAAD ${ }^{3}$, HÉLIO MOREIRA DA SILVA JÚNIOR ${ }^{4}$
}

\begin{abstract}
This study evaluated the growth and agro-industrial productivity of sugarcane varieties subjected to different irrigation levels in the county of Penápolis - São Paulo, Brazil. The experimental design was a randomized block with a factorial arrangement of $2 \times 7$ (two cultivars of sugarcane: RB965902 and RB855453, at seven irrigation levels: $\mathrm{L} 0=0 \%, \mathrm{~L} 1=25 \%, \mathrm{~L} 2=50 \%, \mathrm{~L} 3=75 \%, \mathrm{~L} 4=100 \%, \mathrm{~L} 5=125 \%$, and L6 $=150 \%$ of crop evapotranspiration - ETc) with four replicates. The irrigation system was a subsurface drip at a flow rate of $1.4 \mathrm{~L} \mathrm{~h}^{-1}$. The variables evaluated were tillering, culm length, leaf area index (LAI), dry matter, and industrial productivity. The maximum number of plants per linear meter was 30 for variety RB965902 at $100 \%$ ETc, and 29 for variety RB 855453 at 125\% of ETc. Maximum tillering occurred at 120 and 150 days after planting (DAP) for RB965902 and RB855453, respectively. The maximum LAI of BR965902 was 9.57 at 210 DAP and 9.81 at 201 DAP for the RB855453 variety. The RB855453 variety produced an average of $178.93 \mathrm{t} \mathrm{ha}^{-1}$ with irrigation and $164.81 \mathrm{tha}^{-1}$ without, while the variety RB965902 produced $164.08 \mathrm{tha}^{-1}$ and $154.61 \mathrm{t} \mathrm{ha}^{-1}$ with and without irrigation, respectively. At harvest, the total recoverable sugars (TRS) were $129.62 \mathrm{~kg} \mathrm{t}^{-1}$ for RB965902 and $131.63 \mathrm{~kg} \mathrm{t}^{-1}$ for RB855443. The RB855453 variety produced on average 14.19 t ha ${ }^{-1}$ more than the RB965902 variety.
\end{abstract}

Keywords: Saccharum officinarum. LAI. Culm length. TRS. Drip.

\section{CRESCIMENTO E PRODUTIVIDADE DE VERIEDADES DE CANA-DE-AÇÚCAR SOB DIFERENTES LÂMINAS DE IRRIGAÇÃO}

\begin{abstract}
RESUMO - O objetivo deste estudo foi avaliar o crescimento e a produtividade agroindustrial de variedades de cana-planta submetidas a lâminas de irrigação no município dePenápolis - SP. O delineamento experimental foi em blocos casualizados com arranjo fatorial de $2 \times 7$ (duas variedades de cana-de-açúcar: RB965902 e RB855453 e sete lâminas de irrigação: $\mathrm{L}_{0}=0 \%, \mathrm{~L}_{1}=25 \%, \mathrm{~L}_{2}=50 \%, \mathrm{~L}_{3}=75 \%, \mathrm{~L}_{4}=100, \mathrm{~L}_{5}=125 \%$ e $\mathrm{L}_{6}=$ $150 \%$ da evapotranspiração da cultura - ETc) e quatro repetições. O sistema de irrigação foi gotejamento subsuperficial com emissores de $1,40 \mathrm{~L} \mathrm{~h}^{-1}$. As variáveis avaliadas foram: perfilhamento, altura de plantas, índice de área foliar (IAF) e produtividade agroindustrial. O número máximo de plantas por metro linear foi 30 para variedade RB965902 com $100 \%$ e 29 para a RB855453 com 125\% da ETc. O perfilhamento máximo ocorreu aos 120 e 150 dias após o plantio (DAP) na RB965902 e RB855453, respectivamente. O IAF máximo da RB965902 foi 9,57 aos 210 DAP e 9,81 aos 240 DAP para a RB855453. A variedade RB855453 irrigada produziu em média $178,93 \mathrm{t} \mathrm{ha}^{-1}$ e $164,81 \mathrm{tha}^{-1}$ em sequeiro, enquanto a variedade RB965902 produziu 164,08t $\mathrm{ha}^{-1} \mathrm{e} 154,61 \mathrm{t} \mathrm{ha}^{-1} \mathrm{em}$ cultivo irrigado e sequeiro, respectivamente. Na colheita, o total de açúcares recuperáveis (ATR) foi 129,62 $\mathrm{kg} \mathrm{t}^{-1}$ na RB965902 e 131,63 $\mathrm{kg} \mathrm{t}^{-1}$ na RB855443. A variedade RB855453 produziu em média $14,19 \mathrm{t} \mathrm{ha}^{-1}$ a mais do que a RB965902.
\end{abstract}

Palavras-chave: Saccharum ofiicinarum. IAF. Comprimento do colmo. ATR. Gotejamento.

\footnotetext{
*Corresponding author

${ }^{1}$ Received for publication in $05 / 18 / 2015$; accepted in 06/04/2016.

Paper extracted from the doctoral thesis of the first autor.

${ }^{2}$ Hydraulic and Irrigation Laboratory, Instituto Federal Goiano, Campus Rio Verde, GO, Brazil; ctsc2007@hotmail.com.

${ }^{3}$ Rural Engineering Department, Universidade Estadual Paulista “Júlio de Mesquita Filho” Botucatu, SP, Brazil; joaosaad@fca.unesp.br.

${ }^{4}$ Fundação Educacional Penápolis, Penápolis, SP, Brasil; moreirahelio@hotmail.com.
} 


\section{INTRODUCTION}

Sugarcane (Saccharum officinarum) is a crop of great social and economic importance for Brazil, the world's largest producer, as it generates employment and foreign export. The state of São Paulo (SP) is the largest producer of sugarcane in Brazil, responsible for $52 \%$ of all sugarcane processed for sugar and alcohol production in the country. In the harvest of 2015/2016, SP was responsible for the production of 367.6 million tons of sugarcane in an area of approximately 4.5 million hectares (CONAB, 2016).

The sucro-energy sector has suffered from diverse problems, such as a lack of water, as rainfall is not always sufficient to satisfy the water requirements of plants, was well as poor water distribution. This has led to the application of additional irrigation that when well managed and used with the right plant variety, increases productivity and excellent financial returns. In subsurface drip irrigation, water is applied directly to the root system of the crop using buried drip tubes to maintain the soil moisture in the root area near to the field capacity (BERNARDO et al., 2008).

In spite of the advanced technology used in sugarcane production, the sector still lacks substantial information, especially in relation to the factors involved in the growth of sugarcane subjected to different water availability. Various studies carried out in Brazil evaluated only production elements, without considering the physiological responses of the crop during its development (DANTAS NETO et al., 2006; DALRI et al., 2008).

Therefore, the analysis of crop growth cycles allows a sequential assessment of various development phases of the plant (SANTOS et al.,
2009) and subsequently the quantification of growth rates in different environmental conditions, which is considered a standard method of measuring biological productivity in plant species (OLIVEIRA et al., 2004). In addition, it provides information without the need for special equipment or environmental conditions.

Knowledge of crop responses during the vegetative cycle allows us to establish the appropriate management and to improve the efficiency of fertilizer application, irrigation, and timing of planting, so that the highest growth phase coincides with the greatest water availability (RAMESH, 2008).

Sugarcane may be influenced by different levels of irrigation during its growth (DANTAS NETO et al., 2006; GONVCALVES et al., 2009). In addition, morphophysiological development of the plant is also affected by water availability, with a reduction in tillering and the number of culms suitable for processing (FARIAS et al., 2008).

This study aimed to evaluate the growth and productivity of two varieties of sugarcane during the first-cut cycle, when subjected to different irrigation levels, in the municipality of Penápolis - SP.

\section{MATERIAL AND METHODS}

The experiment was conducted in a 0.5 -ha area in the farm of São Francisco, Penápolis - SP, at the geographical coordinates of $21^{\circ} 15^{\prime} 00^{\prime \prime} \mathrm{S}, 50^{\circ}$ $02^{\prime} 00^{\prime \prime} \mathrm{W}$, at an altitude of $415 \mathrm{~m}$. The soil in the experimental area was classified as dystrophic Red Latosol, with medium sandy texture (EMBRAPA, 2013), according to its chemical characteristics (Table 1).

Table 1. Chemical characteristics of the soil at a depth of $0-20 \mathrm{~cm}$.

\begin{tabular}{|c|c|c|c|c|c|c|c|c|c|}
\hline \multirow{3}{*}{$\begin{array}{l}\mathrm{pH} \\
\mathrm{CaCl}_{2}\end{array}$} & \multirow{3}{*}{$\begin{array}{l}\text { M.O } \\
\text { g dm }^{-3} \\
14\end{array}$} & \multirow{3}{*}{$\begin{array}{l}P_{\text {resina }} \\
\mathrm{mg} \mathrm{dm}^{-3} \\
40\end{array}$} & $\mathrm{H}+\mathrm{Al}$ & K & $\mathrm{Ca}$ & $\mathrm{Mg}$ & SB & CTC & V \\
\hline & & & \multicolumn{6}{|c|}{----------- $\mathrm{mmol}_{\mathrm{c}} \mathrm{dm}^{-3}$------ } & $-\%$ \\
\hline & & & 25 & 2.8 & 22 & 5.0 & 29.8 & 54.8 & 54 \\
\hline
\end{tabular}

Soil preparation consisted of subsoiling, plowing, grading, and contouring. The initial fertilizer application was based on chemical analysis of the soil, with a view to achieving productivity of over $100 \mathrm{t} \mathrm{ha}^{-1}$. To achieve this, we applied $30 \mathrm{~kg}$ $\mathrm{ha}^{-1}$ of nitrogen in the form of urea, $180 \mathrm{~kg} \mathrm{ha}^{-1}$ of $\mathrm{P}_{2} \mathrm{O}_{5}$ in the form of triple superphosphate, and $120 \mathrm{~kg}$ $\mathrm{ha}^{-1}$ of $\mathrm{K}_{2} \mathrm{O}$ in the form of potassium chloride, following RAIJ et al. (1997).

The experimental design was in random blocks, with a factorial arrangement $(2 \times 7)$ of two varieties of sugarcane (RB965902 and RB855453) and seven irrigation levels $\left(\mathrm{L}_{0}=0 \%, \mathrm{~L}_{1}=25 \%, \mathrm{~L}_{2}=\right.$ $50 \%, \mathrm{~L}_{3}=75 \%, \mathrm{~L}_{4}=100 \%, \mathrm{~L}_{5}=125 \%$, and $\mathrm{L}_{6}=$ $150 \%$ ) of crop evapotranspiration (ETc), with four replicates.
Planting was carried out in double rows with $0.60 \mathrm{~m}$ between the two rows. The spacing between each set of double rows was $1.40 \mathrm{~m}$. The irrigation system used was a subsurface drip feeding system, with each drip dispenser spaced $50 \mathrm{~cm}$ apart and a flow rate of $1.40 \mathrm{~L} \mathrm{~h}^{-1}$ (autocompensating).

Meteorological data to estimate the reference evapotranspiration $\left(\mathrm{ET}_{\mathrm{O}}\right)$ and to manage the irrigation was obtained from a meteorological station installed in the experimental area. The $\mathrm{ET}_{\mathrm{O}}$ was estimated using the "Class A pan" method employing the equation $(\mathrm{ETo}=\mathrm{Kp} \times \mathrm{ECA})$, in which: $\mathrm{ECA}=$ water evaporation observed in the "Class A pan" $\left(\mathrm{mm}\right.$ day $\left.^{-1}\right) ; \mathrm{Kp}=$ pan adjustment coefficient (dimensionless). The daily value of $\mathrm{Kp}$ was estimated from the following equation $(\mathrm{FAO} / 56)$ 
(ALLEN et al., 1998):

$\mathrm{Kp}=0.108-0.0286 \mathrm{U}+0.0422 \operatorname{Ln}(\mathrm{F})+0.1134(\mathrm{~F})-0.0006331[\operatorname{Ln}(\mathrm{F})]^{2} \operatorname{Ln}(\mathrm{H})$

, in which: $\mathrm{U}=$ average daily wind speed at a height of $2 \mathrm{~m}\left(\mathrm{~km} \mathrm{day}^{-1}\right) ; \mathrm{F}=$ length (extent) from the border area $(\mathrm{m}) ; \mathrm{H}=$ average daily relative humidity (\%).
Evapotranspiration of the crop (ETc) was estimated according to the local $\mathrm{ET}_{\mathrm{O}}$ and the crop coefficient (Kc) of DOORENBOS and KASSAM (1994). These values are shown in Table $2($ ETc $=$ ETo $\times \mathrm{Kc})$.

Table 2. Values of the crop coefficient $(\mathrm{Kc})$ for the sugarcane crop in various phases of development during the first crop cycle.

\begin{tabular}{ccc}
\hline Crop age (days) & Months & Crop coefficient (Kc) \\
\hline $0-43$ & May/Jun & 0.40 \\
$44-66$ & Jun/Jul & 0.75 \\
$67-89$ & Jul/Aug & 0.90 \\
$90-155$ & Aug/Set/Oct & 1.00 \\
$156-281$ & Oct/Nov/Dec/Jan/Feb & 1.25 \\
$282-305$ & Feb/Mar & 1.00 \\
$306-320$ & Mar & 0.70 \\
$321-360$ & Mar/Apr & Without irrigation \\
\hline
\end{tabular}

Source: Adapted from DOORENBOS and KASSAM (1994).

At 60 days after planting (DAP), we started the irrigation, adopting a fixed irrigation frequency of every second day. Growth assessments started at 90 DAP and were conducted at 30 day intervals. The evaluation of growth used the number of plants per linear meter, height of plants, and leaf area index (LAI). To determine the length of the culm, we measured the distance from the ground to the last leaf ear segment visible +1 . The number of plants per linear meter was counted. LAI was obtained by dividing the total leaf area of the plants by the land area. The leaf area (LA) was calculated with the following equation: $\mathrm{LA}=\mathrm{L} \times \mathrm{W} \times 0.75 \times(\mathrm{N}+2)$ in which: $\mathrm{L}$ is the leaf length, $\mathrm{W}$ is the leaf width, 0.75 is the correction factor, and $\mathrm{N}$ is the number of leaves open to at least $20 \%$ of the green area (HERMANN; CÂMARA, 1999). The plots consisted of eight crop rows, and the four central rows of each plot were used to determine the productivity at 360 DAP.

The results were analyzed using analysis of variance and significant differences were tested using the $F$ test $(\mathrm{P}<0.05)$. The Scott-Knott test was applied at 0.05 probability to compare averages.

\section{RESULTS AND DISCUSSION}

Table 3 shows rainfall distribution, irrigation levels, and average air temperature throughout the crop cycle. Cumulative rainfall was $1,453.75 \mathrm{~mm}$. We applied 130.85, 261.77, 392.64, 523.54, 654.40, and $785.29 \mathrm{~mm}$ to represent the irrigation levels of $25 \%, 50 \%, 75 \%, 100 \%, 125 \%$, and $150 \%$ of ETc, respectively. The volume of water applied at the irrigation level corresponding to $25 \%$ of Etc, combined with rainfall, was within the recommended annual range of $1,500-2,000 \mathrm{~mm}$ for sugarcane. This amount of water supply is sufficient for optimal productivity (INMAN-BAMBER; SMITH, 2005) if it is well distributed over the crop lifecycle.

The rainfall during the experiment was $142.94 \mathrm{~mm}$, which was $9.86 \%$ above the average $(1,312.89 \mathrm{~mm})$ for the same period between 1990 and 2015. Rainfall in the rainy season was $1,409.21$ $\mathrm{mm}$, corresponding to $96.93 \%$ of the annual rainfall, while in the dry season, only $44.50 \mathrm{~mm}$ of rainfall was recorded, corresponding to $3.06 \%$ of the annual rainfall. In January, it rained the equivalent of $28.38 \%$ of the entire annual rainfall (Table 3).

The highest levels of irrigation were concentrated between July and October when the plants were between 90 and 180 DAP. After that, irrigation levels were reduced until the end of the experiment. The greatest volume of rainfall was between January and March. From January, rainfall was almost sufficient to meet the water requirements of the crop with only $9.02 \mathrm{~mm}$ of irrigation required at the beginning of March (Table 3).

There was minimal variation in air temperature throughout the crop cycle, with a maximum of $28.97{ }^{\circ} \mathrm{C}$ in November and a minimum of $20^{\circ} \mathrm{C}$ in May 2010 . The average temperature was $24.03{ }^{\circ} \mathrm{C}$ (Table 3). The base temperature for sugarcane is around $20^{\circ} \mathrm{C}$, and the ideal temperature range for optimal growth is within an average daily temperature range of $22-30{ }^{\circ} \mathrm{C}$. In these conditions, the crop shows maximum growth and at temperatures under $20{ }^{\circ} \mathrm{C}$ and over $38{ }^{\circ} \mathrm{C}$, the culm do not lengthen (DOREMBOS; KASSAM, 1994).

For the south and southeast regions of Brazil, temperatures of $18-20{ }^{\circ} \mathrm{C}$ are critical for sugarcane growth. Thus, the average temperature range during the crop period was within the range suitable for sugarcane, which, according to MAGALHÃES (1987), should vary between 20 and $30{ }^{\circ} \mathrm{C}$. Therefore, temperature was not a limiting factor for crop growth. 
Table 3. Rainfall (Pp, mm), irrigation levels, and average air temperature $\left(\mathrm{T}_{\mathrm{m}}{ }^{\circ} \mathrm{C}\right)$ in the first-cut cycle, between May 2010 and May 2011 in Penápolis - SP.

\begin{tabular}{|c|c|c|c|c|c|c|c|c|}
\hline \multirow[t]{2}{*}{ Month } & \multirow[t]{2}{*}{$\mathrm{Pp}(\mathrm{mm})$} & \multicolumn{6}{|c|}{ Irrigation levels (mm) } & \multirow[t]{2}{*}{$\mathrm{T}_{\mathrm{m}}\left({ }^{\circ} \mathrm{C}\right)$} \\
\hline & & L1 & L2 & L3 & L4 & L5 & L6 & \\
\hline May & 0.00 & 6.04 & 12.08 & 18.13 & 24.17 & 30.21 & 36.25 & 20.00 \\
\hline June & 0.00 & 8.24 & 16.48 & 24.72 & 32.96 & 41.20 & 49.44 & 20.50 \\
\hline July & 2.00 & 17.24 & 34.48 & 51.73 & 68.97 & 86.21 & 103.45 & 21.08 \\
\hline August & 0.00 & 28.97 & 57.97 & 86.92 & 115.90 & 144.87 & 173.85 & 21.62 \\
\hline September & 161.38 & 28.25 & 56.50 & 84.76 & 113.01 & 141.26 & 169.51 & 23.73 \\
\hline October & 119.35 & 21.49 & 42.99 & 64.49 & 85.99 & 107.49 & 128.98 & 23.96 \\
\hline November & 77.90 & 10.81 & 21.63 & 32.44 & 43.26 & 54.07 & 64.89 & 28.97 \\
\hline December & 170.75 & 7.56 & 15.13 & 22.69 & 30.26 & 37.82 & 45.39 & 27.63 \\
\hline January & 412.56 & 0.00 & 0.00 & 0.00 & 0.00 & 0.00 & 0.00 & 27.60 \\
\hline February & 211.64 & 0.00 & 0.00 & 0.00 & 0.00 & 0.00 & 0.00 & 26.85 \\
\hline March & 255.63 & 2.25 & 4.51 & 6.76 & 9.02 & 11.27 & 13.53 & 24.79 \\
\hline April & 42.50 & 0.00 & 0.00 & 0.00 & 0.00 & 0.00 & 0.00 & 24.64 \\
\hline May & 0.00 & 0.00 & 0.00 & 0.00 & 0.00 & 0.00 & 0.00 & 21.08 \\
\hline Total & $1,453.75$ & 130.85 & 261.77 & 392.64 & 523.54 & 654.40 & 785.29 & *24.03 \\
\hline
\end{tabular}

*Average temperature $\left({ }^{\circ} \mathrm{C}\right)$ during the experiment; $\mathrm{mm}=$ millimeters of rain.

The number of sugarcane plants per linear meter is shown in Figure 1. For the RB965902 variety, we observed that the peak occurred at 120 DAP in all treatments. Meanwhile, the $100 \%$ level of ETc showed better tillering (30 plants per linear meter), and the $150 \%$ level of ETc produced the lowest, with only 23 plants. After 120 DAP, the number of plants steadily declined until harvest, when a $60 \%$ reduction was seen for the $100 \%$ level of ETc, and a $50 \%$ reduction for the $150 \%$ level of ETc, with averages of 10.5 and 11.5 plants per linear meter, respectively. In irrigated sugarcane, Farias et al. (2008) reported a maximum of 24 plants per linear meter, and only 14 plants without irrigation.
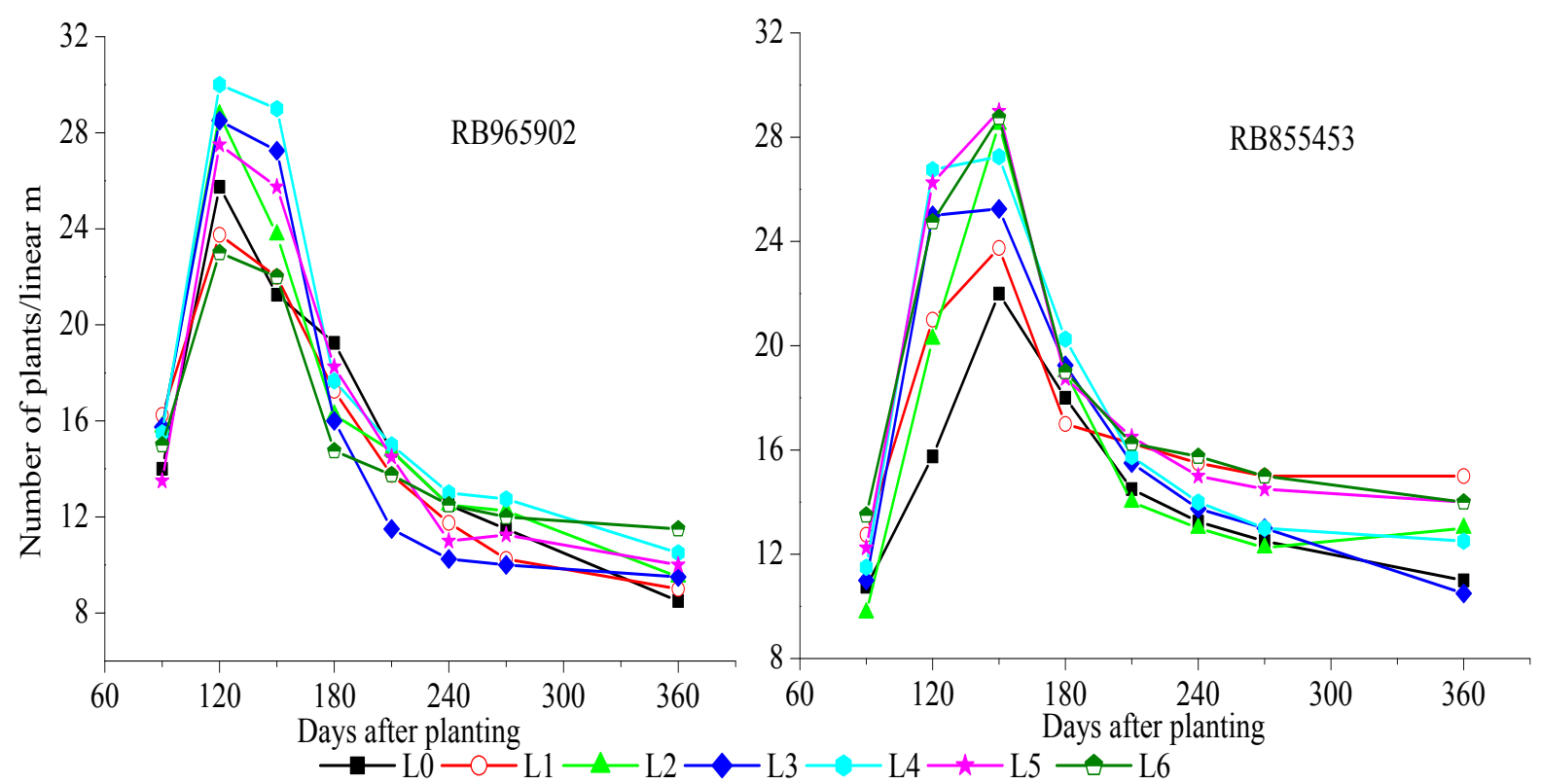

Figure 1. Number of plants per linear meter of sugarcane varieties RB855453 and RB965902, subjected to different irrigation levels in the region of Penápolis - SP, from May 2010 to May 2011.

At 360 DAP, the plots irrigated with $150 \%$ of ETc had, on average, 11.5 plants per linear meter, which was higher than in plots with other levels of irrigation and the non-irrigated plot that had 8.5 plants per linear meter. Even though the $150 \%$ level of ETc had lower values at points during the experiment, it surpassed the other irrigation levels at 360 DAP (Figure 1). Some varieties of sugarcane reach their peak at 120 DAP (CASAGRANDE, 1991). The results for the RB965902 variety are in agreement with those published by Orlando Filho and Rodella (1995), who recorded maximum tillering (29 plants per linear meter) at 120 DAP.

For the variety RB855453, the maximum tillering occurred at $150 \mathrm{DAP}$, and the treatments corresponding to $125 \%$ and $150 \%$ levels of ETc presented the highest numbers of plants per linear meter, which were 29 and 28.75, respectively. Meanwhile, the $0 \%$ level (without irrigation) presented the least number (22 plants). The other 
irrigation levels showed a reduction in numbers of plants up to harvest time, with reductions of $51.72 \%$ for the $125 \%$ level, $51.32 \%$ for the $150 \%$ level, and $50 \%$ for the $0 \%$ level (Figure 1).

The variety RB855453 showed an increase in the number of plants concurrent with greater water availability. Conversely, at 360 DAP the greatest number of plants was observed in the treatment corresponding to the $25 \%$ level of ETc, and the smallest in the $75 \%$ level of ETc (Figure 1). Oliveira et al. (2004) reported a reduction of $27 \%$ for the variety RB72454, $52 \%$ for RB855113, and $57 \%$ for RB855536, between maximum tillering and the harvest time. This response was related to an increase in intra-species competition for resources such as water, light, nutrients, and space, which resulted in the death of the younger, weaker, or more poorly positioned shoots.

The maximum tillering can be achieved in less time than was observed in this study. Ramesh and Mahadevaswany (2000) reported maximum tillering at 120 DAP under conditions of severe and moderate water availability stress, and at 90 DAP in

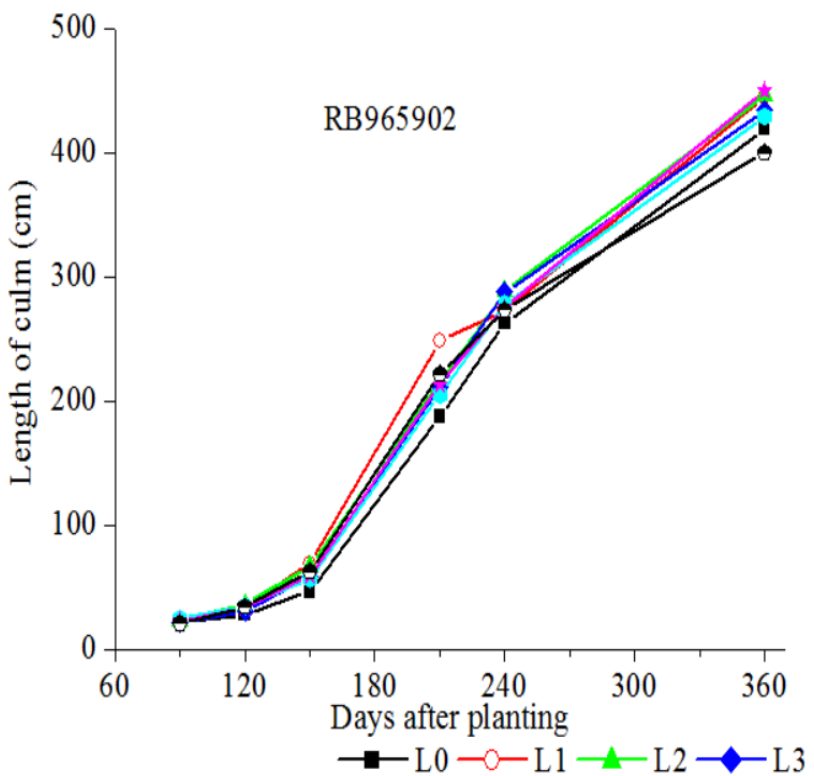

conditions without water stress, with 31,28 , and 34 plants per linear meter, respectively.

The maximum number of tillers in a relatively short period was obtained by Silva et al. (2008) at 90 DAP, with 19 plants per linear meter for the variety RB72454 and 21 for the variety IAC86-2480. Conversely, Dalri et al. (2008) observed the maximum tillering for variety RB72454 at 270 DAP, with 27 and 22 plants per linear meter for irrigated and dry regimes, respectively.

The variation in tillering observed among different authors might result from the interaction between high temperatures and irregular rainfall occurring in the regions where the studies were conducted (SUGUITANI, 2011), in addition to the genetic characteristics of the plants used (OLIVEIRA et al., 2007).

Once the culms started to elongate, there was a reduction in the number of plants for both varieties. After establishing the plant (maximum tillering), the crop started to use resources for vertical growth, with growth rates depending on the variety of plant and irrigation level (Figure 2).

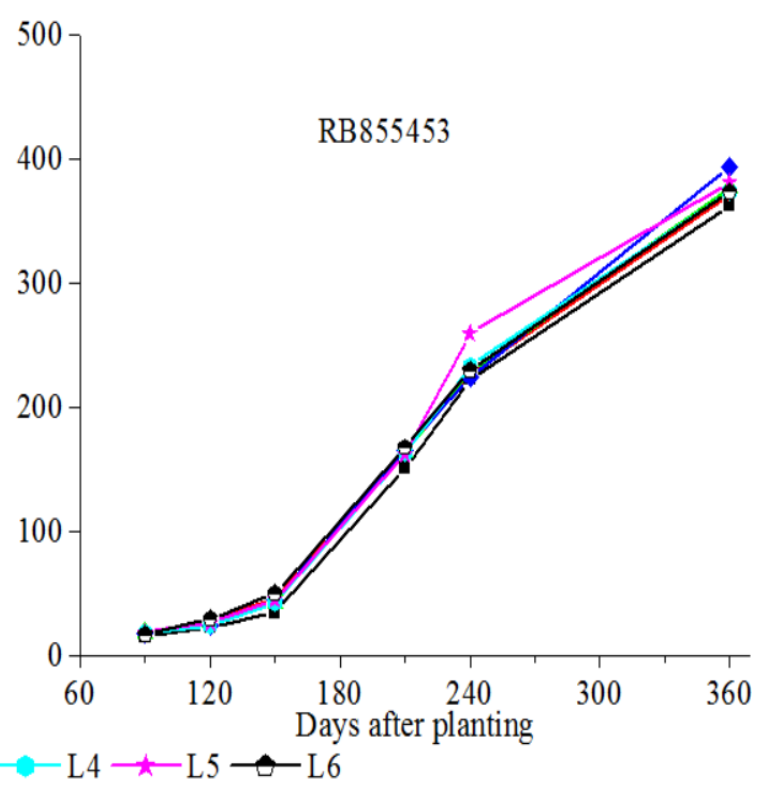

Figure 2. Average culm length (cm) of sugarcane varieties RB855453 and RB965902, subjected to different irrigation levels in the region of Penápolis - SP, from May 2010 to May 2011.

The three growth phases occurred in different periods. The variety RB965902 presented the first phase up to 120 DAP, with an average height of $32.90 \mathrm{~cm}$. During this phase, the $50 \%$ irrigation level provided the fastest growth rate $\left(0.30 \mathrm{~cm} \mathrm{day}^{-1}\right)$ and the $0 \%$ level the slowest rate $\left(0.23 \mathrm{~cm} \mathrm{day}^{-1}\right)$. In addition, the growth was slow as young plants had a small LA, which reduced the solar absorption rate and, thus, the rate of plant growth. Oliveira et al. (2005) reported that the slow growth in the initial phase of the crop was related to the morphological characteristics of the plant canopy, which were not sufficient to capture solar radiation.
The second phase occurred between 120 and 270 DAP. In this period, the growth was rapid and linear, with an average increase of $282.79 \mathrm{~cm}$. The $75 \%$ level of ETc had the fastest growth, growing $1.96 \mathrm{~cm} \mathrm{day}^{-1}$, and the $150 \%$ level had the slowest, with growth of only $1.81 \mathrm{~cm} \mathrm{day}^{-1}$. This same pattern was observed by Alvarez and Castro (1999) and INMAN-BAMBER et al. (2002), who reported that culm elongation coincided with the period in which the LA was greatest.

The third phase (maturation) occurred from 270 to 360 DAP. In general, the maturation process was characterized by a stable number of plants, 
which was maintained at approximately the same level from 270 DAP (Figure 1). Growth was reduced for plants in the $125 \%$ level of ETc treatment, which showed an average increase of $116.04 \mathrm{~cm}$ and a maximum growth rate of $1.45 \mathrm{~cm} \mathrm{day}^{-1}$. The minimum growth rate was $1.05 \mathrm{~cm} \mathrm{day}^{-1}$ for the $50 \%$ level of ETc treatment. This response occurred as a result of the involvement of photoassimilates in the form of sucrose, which was detrimental to culm elongation (KEATING et al., 1999).

Oliveira et al. (2004) also reported greater growth after maximum tillering, when the variety RB855536 grew $99.2 \mathrm{~cm}$ in only 44 days. Farias et al. (2008) observed a height of $40 \mathrm{~cm}$ at 98 DAP for the variety SP79-1011, reaching maximum heights of $152.8 \mathrm{~cm}$ at 194 DAP under irrigation and 148.1 $\mathrm{cm}$ at $236 \mathrm{DAP}$ without irrigation.

The variety RB855453 showed the first phase of development up to 150 DAP, when plants showed an average height of $43.74 \mathrm{~cm}$. The $150 \%$ level of ETc enabled the fastest growth rate $\left(0.33 \mathrm{~cm} \mathrm{day}^{-1}\right)$ and the $0 \%$ level the slowest rate $\left(0.24 \mathrm{~cm} \mathrm{day}^{-1}\right)$. In this period, the variety RB855453 showed faster growth rates with increased irrigation. The second phase of growth occurred between 150 and 300 DAP, where an average increase of $260.59 \mathrm{~cm}$ was observed. In this phase, the $125 \%$ level of ETc produced the fastest growth rate $\left(1.84 \mathrm{~cm} \mathrm{day}^{-1}\right)$ and $0 \%$ the slowest growth rate $\left(1.68 \mathrm{~cm} \mathrm{day}^{-1}\right)$.

The third growth phase for the variety RB855453 occurred between 300 and 360 DAP, with an average increase of $72.02 \mathrm{~cm} \mathrm{day}^{-1}$. The fastest and slowest growth rates were observed for levels of irrigation at $75 \%$ and $125 \%$ of ETc, which were 1.41 and $1.02 \mathrm{~cm} \mathrm{day}^{-1}$, respectively. For the variety $\mathrm{RB} 855453$, the $150 \%$ level of ETc provided the

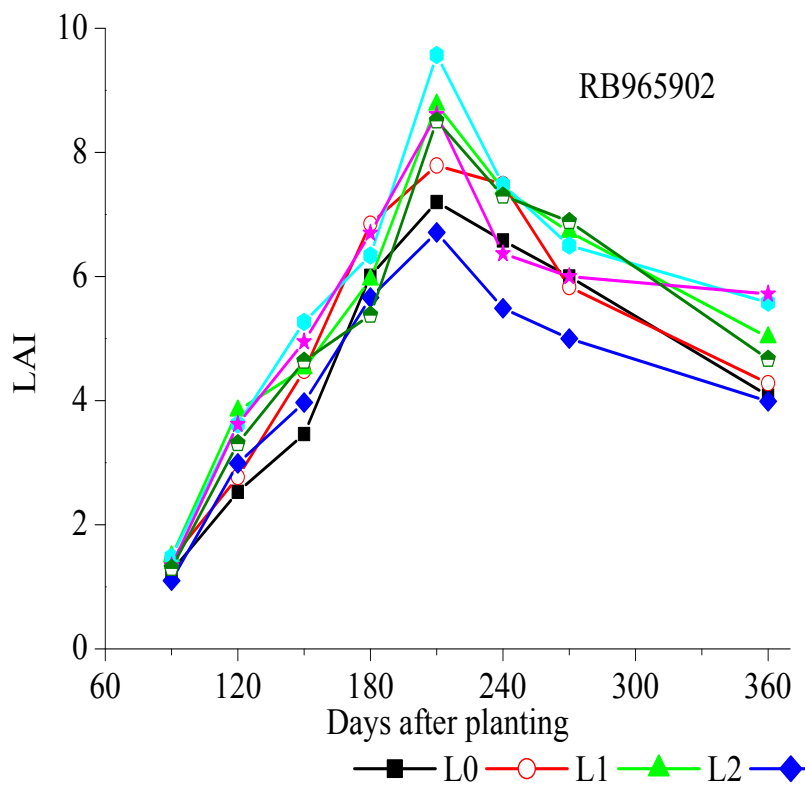

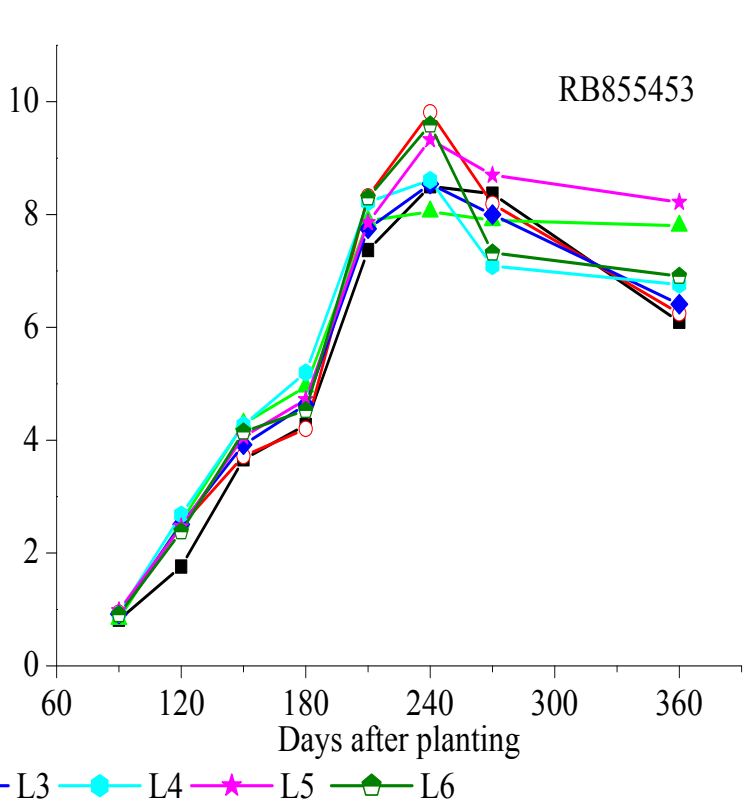

fastest growth rate only in the first growth phase. During the phase of the fastest growth of the sugarcane plant in the region of Paranavaí (PR), Oliveira et al. (2005) reported rates of culm elongation of $1.6 \mathrm{~cm} \mathrm{day}^{-1}$ for the variety RB855113, $1.8 \mathrm{~cm} \mathrm{day}^{-1}$ for the variety RB855536, and $2.0 \mathrm{~cm}$ day $^{-1}$ for the variety RB72454, and attributed the reduced rate of culm growth to the plant self-shading during maturation. The growth and death of tillers in sugarcane has been greatly affected by lack of water in India (RAMESH; MAHADEVASWAMY, 2000).

The two varieties in this study, which were cultivated under the same water availability conditions, exhibited different responses in the various phases of development. These responses showed that variety RB965902 was less affected when subjected to different treatments, presenting faster overall growth rates. However, the variety RB855453 showed inferior size at harvest time (Figure 2). The variation in the height of the plant is an indication of either tolerance or susceptibility of the plant variety to the lack of water (SILVA et al., 2008).

Figure 3 shows the LAI values of the two sugarcane varieties subjected to the different irrigation levels. The LAI reflects the capacity of the plant to efficiently convert solar energy into biomass, and is therefore important for predicting the capture of solar radiation during photosynthesis. The maximum LAI occurred in different periods of crop development, at 210 DAP for the variety RB965902 and at 240 DAP for RB855453. An increased irrigation level did not provide the maximum LAI across the different seasons of the experiment (Figure 3).

Figure 3. Leaf area index of the sugarcane varieties RB855453 and RB965902 subjected to different irrigation levels in the region of Penápolis - SP, from May 2010 to May 2011. 
The variety RB965902 showed increasing linear growth until 210 DAP, when LAI reached an average value of 8.17 . The maximum LAI (9.57) was observed when the crop was irrigated at $100 \%$ of ETc, and the minimum (6.71) with irrigation at $75 \%$ of ETc. After 210 DAP, LAI started to decline until the harvest time (Figure 3).

The observed reduction between the maximum LAI and the harvest time was $41.63 \%$ and $40.60 \%$ for the $100 \%$ and $75 \%$ levels of ETc, respectively (Figure 3). Therefore, if the number of plants per linear meter started to decline from 120 DAP (Figure 1), i.e., the time at which LAI growth continued to accelerate, it is evident that the number of plants was influenced by an increased number of leaves and dimensions of the LA. At 360 DAP, the LAI of plots irrigated with the equivalent of $125 \%$ of ETc (5.72), was higher than LAI in plots irrigated at other levels, while the plots irrigated with the equivalent of $75 \%$ of ETc had the lowest LAI (3.99).

The variety RB855453 presented three growth phases in relation to LAI. The first occurred between planting and 180 DAP (Figure 3), characterized by a slow growth with an average LAI of 4.64. In this period, the maximum and minimum values were observed in the levels corresponding to $100 \%$ (5.2) and 25\% (4.2) of ETc, respectively. The second development phase was marked by rapid linear growth between 180 and 240 DAP, and was the season in which the maximum LAI was observed in the $25 \%$ of ETc plots (9.81), and the minimum in the $50 \%$ of ETc plots $(8.05)$. In the third phase, the process of reduction began and continued until the harvest time. This phase produced average LAI values of 6.92 , with a maximum of 8.22 for the treatment corresponding to $125 \%$ of ETc and a minimum of 6.10 without irrigation.

As LAI was influenced by the LA, the number of leaves, and the number of plants, and the latter started to decline between 120 and 150 DAP, it was observed from Figure 3 that leaf senescence occurred in different stages irrespective of water restrictions.

The maximum LAI values observed in this study were higher than that observed in sugarcane plants (4.92) by Robertson et al. (1999), and those obtained under full irrigation at 152 DAP (6.82), and without irrigation at 147 DAP (6.80) by Farias et al. (2008). Additionally, Oliveira et al. (2004) reported a maximum of 4.8 and 5.8 for varieties RB72454 and RB855113, respectively, at 377 DAP, and 4.5 at 323 DAP for the variety RB855536.

For other sugarcane varieties in different cultivation cycles, some authors have observed a maximum LAI of 4.9 at 120 DAP (SANTOS et al., 2009), while in ratoon cane, Almeida et al. (2008) reported LAI of 6.0 at 210 DAP. In this study, we observed a period of high LAI growth until 210 DAP for the variety RB965902 and until 240 DAP for RB855453 (Figure 3), as the rate of leaf emergence may have been higher than leaf senescence in this period. This confirmed that the size of the photosynthetic apparatus was largely established in the period of faster growth rates for both varieties, aiming at higher solar energy capture. Therefore, in the period of maximum development, LAI should be between 9.0 and 12. There was a parabolic function for LAI during the annual cycle of the crop, with low values at the beginning, a peak in the middle, followed by a decline concurrent with leaf senescence and reduced tillering (FARIAS et al., 2007). For Gomide and Gomide (1999) the reduction in the number of leaves and the LA occurred due to the advanced age of the leaves, combined with an increase in respiratory activity.

In relation to this, Machado et al. (1982) reported that the ideal LAI is approximately 4.0, which would be sufficient to capture approximately $95 \%$ of photosynthetically active radiation. The magnitude and duration of LAI is related to the capturing capacity of the canopy. Thus, LAI is correlated with photosynthesis and the accumulation of dry material in unstressed conditions (TAVARES, 2009).

Culm productivity was directly related to growth variables, and this relationship differed between varieties. Figure 4 shows that the variety RB855453 subjected to an irrigation level of $75 \%$ achieved the greatest productivity $\left(189.26 \mathrm{t} \mathrm{ha}^{-1}\right)$, and that this may have been influenced by a greater plant height $(394.17 \mathrm{~cm})$ and culm diameter $(31.33 \mathrm{~mm})$ at 360 DAP (Figures 4A and 4C).

For the variety RB965902, the increased productivity occurred as the irrigation level increased and Figure 4D shows a maximum yield of $173.73 \mathrm{t}$ $\mathrm{ha}^{-1}$, and a greater number of plants per linear meter (11.5). Thus, we observed a correlation between the number of plants and productivity for variety RB965902.

No relationship was observed between LAI and productivity at 360 DAP (Figure 4B), despite the fact that this index directly correlates with the capture of solar radiation during the entire period of crop development, i.e., its influence on biomass production occurs from the time of canopy formation and not just near harvest time.

Table 4 shows the results of analysis of variance of agricultural productivity and agro-industrial attributes. The $F$ test showed that the varieties had significantly different culm productivity $(\mathrm{TCH})$ and tons of sugar per hectare (TSH). 

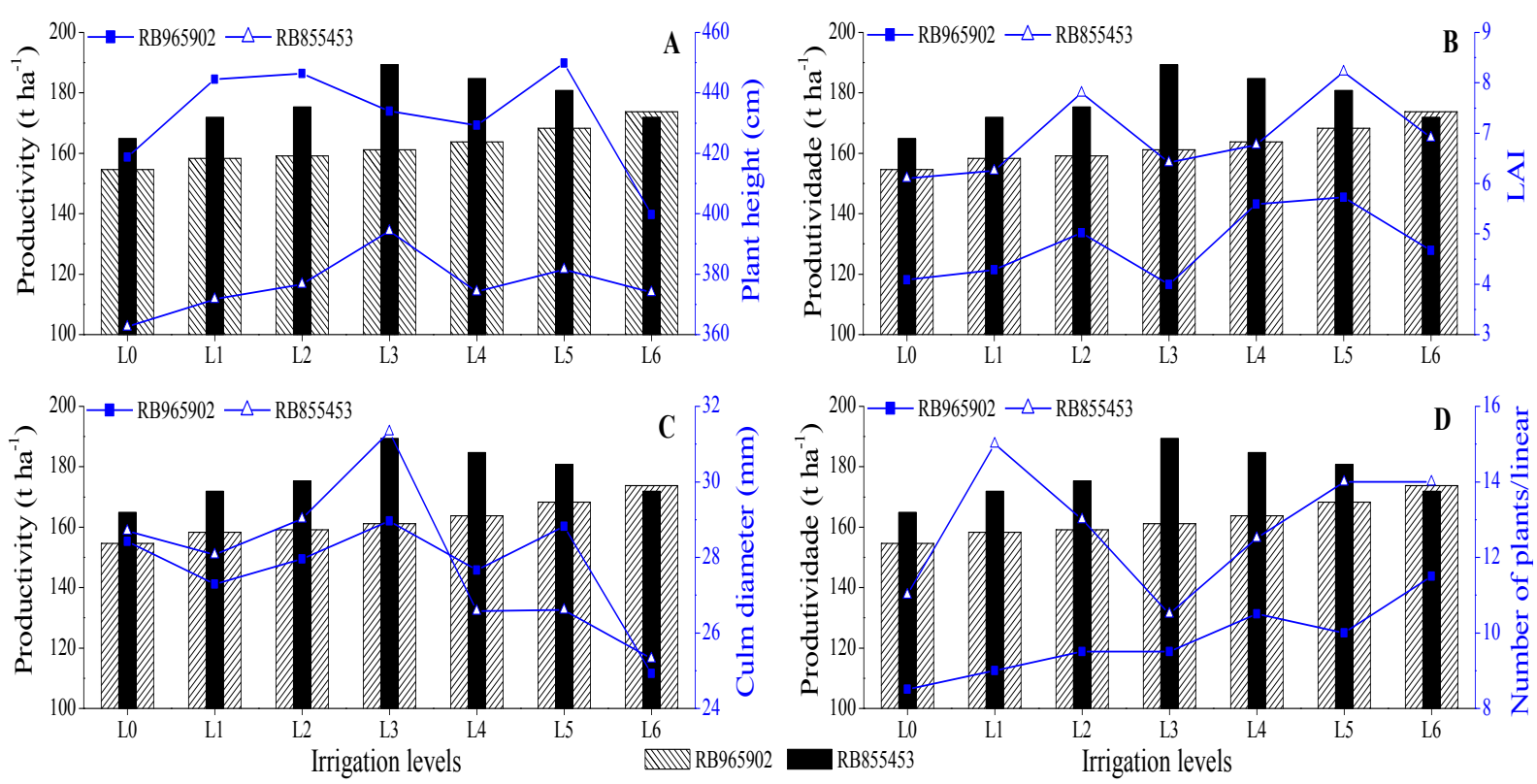

Figure 4. Culm productivity of two sugarcane varieties subjected to different irrigation levels in the region of Penápolis SP, from May 2010 to May 2011.

Table 4. Analysis of variance ( $F$ test) of culm productivity and agro-industrial attributes of two varieties of sugarcane subjected to different levels of irrigation in the region of Penápolis - SP.

\begin{tabular}{lllll}
\hline Causes of variation & GL & TCH & TSH & TRS \\
\hline Varieties (V) & 1 & $15.01^{*}$ & $5.44^{*}$ & $0.88^{\text {ns }}$ \\
Levels (L) & 6 & $1.49^{\text {ns }}$ & $1.71^{\text {ns }}$ & $1.35^{\text {ns }}$ \\
V $\times$ L & 6 & $0.92^{\text {ns }}$ & $0.39^{\text {ns }}$ & $0.56^{\text {ns }}$ \\
Blocks & 3 & $0.82^{\text {ns }}$ & $2.38^{\text {ns }}$ & $9.72^{*}$ \\
Residue & 39 & & & \\
\hline Total & 55 & & 11.12 & 6.13 \\
\hline CV (\%) & & 8.07 & $21.56 \mathrm{~b}$ & $131.63 \mathrm{a}$ \\
\hline RB965902 & $162.73 \mathrm{~b}$ & $23.11 \mathrm{a}$ & $129.62 \mathrm{a}$ \\
RB855453 & $176.92 \mathrm{a}$ & 22.33 & 130.62 \\
\hline General average & 169.82 & & \\
\hline
\end{tabular}

*Significant or non-significant (ns) at $5 \%$ probability by the $F$ test. Averages followed by the same letter within a column are not significantly different from each other by the Scott-Knott test. TCH $=$ tons of cane per hectare, TSH $=$ tons of sugar per hectare, and TRS $=$ total recoverable sugars $\left(\mathrm{kg} \mathrm{t}^{-1}\right)$.

Table 4 shows that the variety RB855453 presented an average productivity higher than RB965902. Average yields of 178.93 and $164.81 \mathrm{t} \mathrm{ha}^{-1}$ were observed for variety RB855453 in the irrigated and non-irrigated treatments, respectively. Average yields of 164.08 and $154.61 \mathrm{t} \mathrm{ha}^{-1}$ were observed for RB965902 in the irrigated and non-irrigated treatments, respectively. Under the same conditions, the variety RB 855453 presented an average increase of $14.19 \mathrm{t} \mathrm{ha}^{-1}$, indicating possible greater efficiency in the use of water. The average productivity of non-irrigated plots was $159.71 \mathrm{t} \mathrm{ha}^{-1}$, which was above the Brazilian average $\left(76.7 \mathrm{tha}^{-1}\right)$ for SP $\left(81.7 \mathrm{tha}^{-1}\right)$ and for the northeast $\left(49.3 \mathrm{t} \mathrm{ha}^{-1}\right)$ in the harvest of 2015/2016 (CONAB, 2016).

Experimental results from various regions of Brazil published by RIDESA revealed that the variety RB965902 produced $128.50 \mathrm{t} \mathrm{ha}^{-1}$ in the sugarcane plant cycle, $119.70 \mathrm{tha}^{-1}$ in the first ratoon cut, and $113.50 \mathrm{t} \mathrm{ha}^{-1}$ in the second ratoon cut.
Meanwhile, the variety RB855453 produced $128.30 \mathrm{t}$ $\mathrm{ha}^{-1}$ in the first-cut cycle, $115.10 \mathrm{t} \mathrm{ha}^{-1}$ in the first ratoon cut, and $114.90 \mathrm{t} \mathrm{ha}^{-1}$ in the second ratoon cut, in non-irrigated crops (DAROS et al., 2010), which are all lower than the results in this study.

Some studies carried out with drip irrigation of sugarcane in various regions of the country report results that are similar to or higher than those in this study. In the region of Botucatu (SP), DALRI et al. (2008) reported productivity of $300.46 \mathrm{t} \mathrm{ha}^{-1}$ with irrigation, and $202.23 \mathrm{t} \mathrm{ha}^{-1}$ without irrigation. In the region of Jaú (SP), Silva et al. (2008) reported yields of $78.18 \mathrm{tha}^{-1}$ for the variety IAC86-2480 and 90.30 $\mathrm{t} \mathrm{ha}^{-1}$ for RB72454 without irrigation.

For tons of sugar per hectare (TSH), a significant effect was observed only between varieties, with RB855453 showing higher TSH than RB965902. Considering that TSH is influenced by agricultural productivity and sucrose concentration in the cane, we emphasize that these two variables are better expressed in the variety RB 855453 . The 
average values observed were $23.11 \mathrm{t} \mathrm{ha}^{-1}$ for the variety RB855453 and $21.56 \mathrm{t} \mathrm{ha}^{-1}$ for RB965902 (Table 4).

The sugar yields obtained in this study, which were $16.14 \mathrm{t} \mathrm{ha}^{-1}$ for the variety RB965902 and $16.29 \mathrm{t} \mathrm{ha}^{-1}$ for RB855453 (Table 4), were higher than the averages reported by Daros et al. (2010), in three crop cycles, with the same genetic varieties. Under non-irrigated conditions, Silva et al. (2008) also observed significant differences between varieties with $12.28 \mathrm{t} \mathrm{ha}^{-1}$ for the variety IAC86-2480 and $14.42 \mathrm{t} \mathrm{ha}^{-1}$ for RB72454.

Of the elements analyzed, total recoverable sugars (TRS) is the most important for both industry and producers, as some agro-industrial organizations use TRS to create the table of prices paid to producers in some regions of the country.

The average values of TRS observed were $129.62 \mathrm{~kg} \mathrm{t}^{-1}$ for the variety RB855453 and $131.63 \mathrm{~kg} \mathrm{t}^{-1}$ for RB965902 (Table 4), which were considered lower than the Brazilian national average $\left(131.4 \mathrm{~kg} \mathrm{t}^{-1}\right)$ from the harvest of 2015/2016. Dalri et al. (2008) reported a significant difference between different treatments with $152.68 \mathrm{~kg} \mathrm{t}^{-1}$ in irrigated sugarcane and $148.79 \mathrm{~kg} \mathrm{t}^{-1}$ in non-irrigated sugarcane. Paula (2008) reported average values of $140.13 \mathrm{~kg} \mathrm{t}^{-1}$ in sugarcane and 135.59 in the first ratoon cut, and Silva et al. (2008) reported yields of $153.92 \mathrm{~kg} \mathrm{t}^{-1}$ and $154.84 \mathrm{~kg} \mathrm{t}^{-1}$ for varieties IAC86-2480 and RB72454, respectively. The results obtained in this study were lower for both varieties than those previously reported. However, the TRS was directly related to the genetic characteristics of the varieties and the rainfall during the harvest time.

\section{CONCLUSIONS}

The varieties RB965902 and RB855453 showed maximum tillering at 120 and 150 days after planting respectively.

The variety RB855453 was more productive in culms and sugar.

Culm productivity was positively correlated with the number of plants per linear meter and with LAI for the variety RB855453.

Irrigation levels influenced culm productivity.

The variety RB965902 presented greater plant height and greater productivity in plots receiving an irrigation level equivalent to $150 \%$ of ETc.

\section{REFERENCES}

ALMEIDA, A. C. dos S. et al. Desenvolvimento vegetativo e produção de variedades de cana-de-açúcar em relação à disponibilidade hídrica e unidades térmicas. Ciência e Agrotécnologia, Lavras, v. 32, n. 5, p. 1441-1448, 2008.
ALLEN, R. G. et al. Crop evapotranspiration -Guidelines for computing crop water requerimentes. Rome FAO, 1998. 301 p. (FAO Irrigation and Drainage, 56).

ALVAREZ, I. A.; CASTRO, P. R. C. Crescimento da parte aérea da cana crua e queimada. Scientia Agrícola, Piracicaba, v. 56, n. 4, p. 1069-1079, 1999.

BERNARDO, S.; SOARES, A. A.; MANTOVANI, E. C. Manual de Irrigação. 8 ed. Viçosa, MG: Editore Universitária, 2008. 625 p.

CASAGRANDE, A. A. Tópicos de morfologia e fisiologia da cana-de-açúcar. Jaboticabal, SP: FUNEP, 1991. 157 p.

COMPANHIA

NACIONAL

$\mathrm{DE}$

ABASTECIMENTO. Acompanhamento da safra brasileira: Cana-de-açúcar. Disponível em: $<$ http:// www.conab.gov.br/OlalaCMS/uploads/

arquivos/12_08_09_15_07_05_boletim_cana_portug ues_-_agosto_2016_2o_lev.pdf $>$. Acesso em: 11 maio. 2016

DANTAS NETO, J. et al. Resposta da cana-de-açúcar, primeira soca, a níveis de irrigação e adubação de cobertura. Revista Brasileira de Engenharia Agrícola e Ambiental, Campina Grande, v. 10, n. 2, p. 283-288, 2006.

DALRI, A. B. et al. Irrigação por gotejamento subsuperficial na produtividade e qualidade de cana-de-açúcar. Revista Irriga, Botucatu, v. 13, n. 1, p. $1-11,2008$.

DAROS, E. et al. Liberação nacional de novas variedades "RB" de cana-de-açúcar. Rede interuniversitária para o desenvolvimento do setor sucroalcooleiro. 3. ed. Curitiba, PR: 2010, 64 p.

DOOREMBOS, J.; KASSAM, A, H. Efeito da água no rendimento das culturas. Tradução de $H$. $R$. GHEYI, A. A DE SOUZA, F. A. V. DAMASCENO, J. F. DE MEDEIROS, Campina Grande: Universidade Federal de Paraíba, 1994, p. 220-226. (Estudos FAO: Irrigação e Drenagem, 33).

EMBRAPA. Sistema brasileiro de classificação de solos. 2. ed. Rio de Janeiro, RJ: EMBRAPA - CNPS, 2006. 306 p.

FARIAS, C. H. de A. et al. Índice de área foliar em cana-de-açúcar sob diferentes níveis de irrigação e zinco na paraíba. Revista Caatinga, Mossoró, v. 20, n. 4 , p. $45-55,2007$.

FARIAS, C. H. de A. et al. Índices de crescimento da cana-de-açúcar irrigada e de sequeiro no Estado 
da Paraíba. Revista Brasileira de Engenharia Agrícola e Ambiental, Campina Grande, v. 12, n. 4, p. 356-362, 2008.

GOMIDE, C. A. M.; GOMIDE, J. A. Análise de crescimento de cultivares de Panicum maximu Jacq. Revista Brasileira de Zootecnia, Viçosa, MG, v. 28, n. 3, p. 675-680, 1999.

GONÇALVES, E. R. et al. Trocas gasosas e fluorescência da clorofila $a$ em variedades de cana-de-açúcar submetidas à deficiência hídrica. Revista Brasileira de Engenharia Agrícola e Ambiental, Campina Grande, v. 14, n. 4, p. 378-386, 2009.

HERMANN, E. R.; CÂMARA， G. M. S. Um método simples para estimar a área foliar de cana-de-açúcar. Revista STAB - Açúcar, Álcool e Subprodutos, Piracicaba, v. 17, n. 5, p. 32-34, 1999.

INMAN-BAMBER, N. G.; MUCHOW, R. C.; ROBERTSON, M. J. Dry partitioning of sugarcane in Australia and South Africa. Field Crops Research, Amsterdam, v. 76, n. 5, p. 71-84, 2002.

INMAN-BAMBER, N. G.; SMITH, D. M. Water relations in sugarcane and response to water deficits. Field Crops Research, Amsterdam, v. 92, n. 3, p. 185-202, 2005.

KEATING, B. A. et al. Modelling sugarcane production systems I: development and performace of the sugarcane module. Field Crops Research, Amsterdam, v. 48, n. 2, p. 27-36, 1999.

MACHADO, E. C. et al. Índices biométricos de duas variedades de cana-de-açúcar. Pesquisa Agropecuária Brasileira, Brasília, v. 17, n. 9, p. 1323-1329, set. 1982.

MAGAlHÃES, A. C. N. Ecofisiologia da cana-de-açúcar, aspectos do metabolismo do carbono na planta. In: CASTRO, P. R. C.; FERREIRA, S. O.; YAMADA, T. Y. (Eds.). Ecofisiologia da produção agrícola. Piracicaba: POTAFOS, 1987, p. 113-118.

OLIVEIRA, R. A. et al. Crescimento e desenvolvimento de três cultivares de cana-de-açúcar, em cana-planta, no estado do Paraná. Scientia Agrária, Piracicaba, v. 5, n. 1-2, p. 87-94, 2004.

OLIVEIRA, R. A. et al. Crescimento e desenvolvimento de três cultivares de cana-de-açúcar, em cana-planta, no estado do Paraná: Taxas de crescimento. Scientia Agrária, Piracicaba, v. 6, n. 1-2, p. 85-89, 2005.

OLIVEIRA, R. A. et al. Área foliar em três cultivares de cana-de-açúcar e sua correlação com a produção de biomassa. Pesquisa Agropecuária Tropical, Goiânia, v. 37, n. 2, p. 71-76, 2007.

ORLANDO FILHO, J.; RODELLA, A. A. Adubação nitrogenada em cana planta: perfilhamento e produtividade agrícola. STAB. Açúcar, Álcool e Subprodutos, Piracicaba, v. 13, n. 3, p. 16-18, 1995.

PAULA, A. L. de. Desenvolvimento e produtividade da cana-de-açúcar em ambiente protegido sob diferentes níveis freáticos. 2008. 149 f. Tese (Doutorado em Agronomia: Área de concentração em Irrigação e Drenagem) - Escola Superior de Agricultura "Luiz de Queiroz", Universidade de São Paulo, Piracicaba, 2008.

RAIJ, B. et al. Recomendações de adubação e calagem para o Estado de São Paulo. Boletim Técnico do Instituto Agronômico, São Paulo, 2. ed. n. 100,285 p. 1997.

RAMESH, P. Effect of different levels of drought during the formative phase on growth parameters and relationship with dry matter accumulation in sugarcane. Journal of Agronomy and Crop Science, Coimbatore, v. 185, n. 14, p. 83-89, 2008.

RAMESH, P.; MAHADEVASWANY, M. Effect of formative phase drought on different classes of shoots, shoot mortality, cane attributes, yield and quality of four sugarcane cultivars. Journal of Agronomy and Crop Science, Coimbatore, v. 185, n. 14, p. $249-258,2000$

ROBERTSON, M. J. et al. Estimating the risk associated with drying-off strategies for irrigated sugarcane before harvest. Australian Journal of Agricultural Research, Amsterdam, v. 50, n. 1, p. 65-77, 1999.

SANTOS, V. R. dos. et al. Crescimento e produtividade agrícola de cana-de-açúcar em diferentes fontes de fósforo. Revista Brasileira de Engenharia Agrícola e Ambiental, Campina Grande, v. 13, n. 4, p. 389-396, 2009.

SILVA, M. A.; JERONIMO, E. M.; DAL'COL LÚCIO, A. Perfilhamento e produtividade de cana-de-açúcar com diferentes alturas de corte e épocas de colheita. Pesquisa Agropecuária Brasileira, Brasília, v. 43, n. 8, p. 979-986, 2008.

SUGUITANI, C. Fenologia da cana-de-açúcar (Saccharum spp.) sob efeito do fósforo. ESALQ, 2001. 79 f. Dissertação (Mestrado em Fitotecnia: Área de Concentração Solos e Nutrição de Plantas) Escola Superior de Agricultura "Luiz de Queiroz", Universidade de São Paulo, Piracicaba, 2011. 
TAVARES, A. C. S. Sensibilidade da cana-de-açúcar (Saccharum spp.) ao excesso de água no solo. 2009. 221 f. Tese (Doutorado em Agronomia: Área de Concentração Irrigação e Drenagem) - Escola Superior de Agricultura "Luiz de Queiroz", Universidade de São Paulo, Piracicaba, 2009. 